\title{
THE DIFFICULTIES OF WRITING THE PAST THROUGH LAW - HISTORICAL TRIALS REVISITED AT THE EUROPEAN COURT OF HUMAN RIGHTS
}

Károly Bárd

\section{ERES | « Revue internationale de droit pénal »}

2010/1 Vol. 81 | pages 27 à 45

ISSN 0223-5404

ISBN 9782749212227

Article disponible en ligne à l'adresse :

https://www.cairn.info/revue-internationale-de-droit-penal-2010-1-page-27.htm

\section{Pour citer cet article :}

Károly Bárd, « The difficulties of writing the past through law - historical trials revisited at the european court of human rights », Revue internationale de droit pénal 2010/1 (Vol. 81), p. 27-45.

DOI 10.3917/ridp.811.0027

Distribution électronique Cairn.info pour ERES.

(C) ERES. Tous droits réservés pour tous pays.

La reproduction ou représentation de cet article, notamment par photocopie, n'est autorisée que dans les limites des conditions générales d'utilisation du site ou, le cas échéant, des conditions générales de la licence souscrite par votre établissement. Toute autre reproduction ou représentation, en tout ou partie, sous quelque forme et de quelque manière que ce soit, est interdite sauf accord préalable et écrit de l'éditeur, en dehors des cas prévus par la législation en vigueur en France. Il est précisé que son stockage dans une base de données est également interdit. 


\title{
THE DIFFICULTIES OF WRITING THE PAST THROUGH LAW - HISTORICAL TRIALS REVISITED AT THE EUROPEAN COURT OF HUMAN RIGHTS
}

\author{
Károly BÁRD*
}

I.

Tribunals, be it international, mixed or domestic trying international crimes which, as a general rule, form part of mass atrocities frequently induced and sponsored by those in power and that have their origin in social or political conflicts (for the sake of brevity I will term these type of trials "historical trials") are expected to fulfill a number of functions. This in fact is also the case with "ordinary courts" trying "ordinary crimes": they too attempt to accomplish a number of goals, such as general deterrence, incapacitation or rehabilitation that are not always easy to be reconciled with each other. But the list of goals of those courts that are meant to deliver "historical or transitional justice" is much longer. "Besides standard objectives of national criminal law enforcement [they] profess to pursue numerous additional aims."1

Historical trials in addition to rendering judgment on the defendant's guilt and imposing punishment in the individual case are expected to send out the message to victims that justice has been done. The court room is regarded as the forum where victims can present their narratives and regain their dignity by this. Courts are also viewed as agencies of truth telling. "The claim is that the process of subjecting evidence to forensic scrutiny will set down a permanent record of the crimes that will stand the test of time."2 It is argued that historical trials may have an important role in post-conflict reconciliation and in advancing universal human rights values. Later, I will come back to the tensions created by the multiplicity of functions historical trials are expected to perform.

A further particularity of historical trials is that their impact goes well beyond the individual case. First, judgments rendered in "historical trials" shape the law to a

\footnotetext{
* Professor, Central European University, Budapest.

1 Mirjan Damaska: What is the Point of International Criminal Justice? 83 Chicago-Kent Law Review 329, 331 (2008).

2 Robert Cryer - Håkan Friman - Derryl Robinson - Elizabeth Wilmhurst: An Introduction to International Criminal Law and Procedure. Cambridge, 2007, Cambridge University Press, p. 24.
} 
much greater extent than decisions passed in "ordinary trials" by "ordinary courts". The latter primarily under the continental approach are expected to confine themselves to applying and interpreting the law rather than to developing it. In ordinary trials a well-established body of national law is to be applied, and there is little room and need for developing that law through court judgments. In historical trials, in contrast, courts are frequently forced to apply a set of fluid, vague international norms. In the absence of any clear guidance in "positive law" they sometimes have to find out themselves with the help of earlier court judgments and/or scholarly writings what the law was at the time of the events (perpetration/commission of the alleged crime) and set precedents through their decisions for subsequent historical trials.

International crimes can hardly be separated from the socio-political context within which they are perpetrated. Therefore, it is not surprising that the assessment of the judgments they produce is not confined to whether they are legally correct but extends to their socio-political implications. Thus, the reactions on the conviction of Vassily Kononov by the Latvian Supreme Court and the subsequent judgment of the European Court of Human Rights (ECtHR), one of the decisions I will explore in this article, had little to do with the individual trial. Kononov, a partisan fighting on the side of the Soviet Army, was convicted by the Supreme Court of Latvia in 2004 as a war criminal for his involvement in the killing of Latvian villagers who had collaborated with the Germans and contributed to the extermination of another partisan group. The commentators pointed out that the judgment of the Latvian courts in fact reviewed the traditional narrative of World War II that presented the victors as saints and the Germans and their allies as the devils. In 2008 the application filed by Kononov was heard by the ECtHR. The judgment rendered by the Chamber found - with four votes against three Latvia in breach of Article 7 of the European Convention on Human Rights and Fundamental Freedoms (ECHR). The comments posted on the Internet after the publication of the judgment again had little to do with the case itself or with the reasoning of the ECtHR. The bloggers celebrated Russia's moral victory over Latvia and considered the ECtHR judgment as a condemnation of Latvia's efforts to rewrite history. ${ }^{3}$ The case is now pending before the Grand Chamber, and the commentators anticipating the effects of the future ruling of the Grand Chamber point out that a decision of non-violation by Latvia could result in branding the USSR as an occupying power which, in turn, could justify Latvia's claim for compensation. At the same time it is argued that a judgment of non-violation could induce descendents of Jews murdered by Latvian subunits during World War II to make demands for compensation. But beyond the possible legal

\footnotetext{
${ }^{3}$ Available at: http://globalvoiceonline.org/2008/07/27/latvia-european-court-goes-againstriga (last visited on 10/02/2010).
} 
consequences, a Grand Chamber judgment finding that Kononov's conviction by the Latvian Supreme Court was in line with the ECHR could result in repercussions for the Russian minority of Latvia and could provide support for the argument that the role the Soviet Union had played in World War II should be revisited. ${ }^{4}$

The multiple functions of historical trials are also considered when decisions on jurisdiction are rendered: how should the power of prosecuting international crimes be distributed between national and international courts? The question has been answered differently by the drafters of the Nuremberg Charter, the International Criminal Tribunal for the former Yugoslavia (ICTY) and the International Criminal Court (ICC) Statutes. After World War II the Allies had no doubts that it was their exclusive prerogative to try the major war criminals. The ICTY Statute opted for concurrent jurisdiction, with the ICTY having primary jurisdiction, ${ }^{5}$ whereas the principle of complementarity in the ICC Statute gives preference to national courts. ${ }^{6}$ If historical trials are expected to contribute to reconciliation and to recording history then national courts should be given priority over international tribunals. And if national justice systems are not sufficiently equipped for properly handling the cases, mixed or internationalized tribunals are to be set up such as the Special Court for Sierra Leone or the Extraordinary Chambers for Cambodia.

When it comes to the division of jurisdiction between national and international courts, there is a third actor that may enter the scene: international human rights bodies, such as the ECtHR on the European continent. In this context the question of the division of jurisdiction is, of course, formulated differently than is the case in the relation between national and international criminal courts. International human rights bodies and domestic courts are not competing in the sense that they both could have legitimate claims to prosecute and try international crimes. It is clearly in the exclusive competence of national courts to examine and assess the evidence and, by this, to ascertain the facts of the case and to apply and interpret the relevant laws. What the ECtHR is expected to do is to review if the Convention rights were observed. Though in this respect, too, the subsidiarity principle applies in the sense as set forth in the preamble of the Convention: "governments (...) take the first steps for the collective enforcement of certain rights" (emphasis added), meaning that it is primarily up to them to care for the observance of human rights. This is also the explanation for the margin of appreciation doctrine understood in a broad sense. The margin of appreciation, on

\footnotetext{
4 Available at: http://rbth.ru/articles/2009/12/25/251209_kononov.html (last visited on 10/02/2010).

${ }^{5}$ ICTY Statute, Article 9 (2).

${ }^{6}$ ICC Statute, Preamble, par. 10 and Art. 1.
} 
the one hand, is a methodological tool by which the appropriate depth of the review to be exercised by the ECtHR is defined, and which varies - among others according to the Convention right and the question involved. But in addition to serving as a technical device, the margin of appreciation is a substantive concept linked closely to the subsidiarity principle and the doctrine according to which the ECtHR is not a "fourth instance": it lies primarily in the competence of the national authorities to establish the facts of the case and to assess them under their national law. It is not for the ECtHR to review the fact-finding activity of national agencies, nor is it authorized to rule on alleged errors of law. Thus the ECtHR, as a general rule, accepts the findings of fact as they were determined in the national arena, and its jurisdiction is further limited by the fact that, as a principle, it does not extend to the interpretation of national law, nor to the examination of its application. "(I)t is (...) in the first place for the national authorities (...) to interpret and apply the domestic law, the national authorities being in the nature of things particularly qualified to settle the issues arising in this connection."7 Of course, the ECtHR is authorized and obligated to assess if domestic courts when applying the law have observed the rights enshrined in the Convention.

Formulated from the perspective of the ECtHR, the subsidiarity principle calls for self-constraint: the ECtHR cannot assume the functions of national courts, its judgments cannot serve to replace the decisions rendered by domestic courts. In this sense the Court is not an additional instance in the appeals process that stands above the national legal fora. It therefore follows from the subsidiarity principle that the interpretation of national law - as a principal rule - is not the Strasbourg Court's responsibility, and neither is it to uncover potential factual or legal errors committed by the national authorities. The states that are party to the Convention did not assume a responsibility to render materially just decisions, that is to accurately determine the facts of a case and to apply the law correctly.

II.

Following this brief introduction on the subsidiarity principle which will have considerable importance for our further analysis, I come to the subject of my contribution. In the following I will examine judgments of the ECtHR that concerned so-called historical trials conducted by national courts. These ECtHR judgments assessed domestic criminal proceedings in the course of which, in addition to national law, international law and international humanitarian law was to be interpreted and applied. The two cases I selected are Korbely v. Hungary 8

\footnotetext{
${ }^{7}$ Herbert Petzold: The Convention and the Principle of Subsidiarity. In: R. St. J. Macdonald - F. Matscher - H. Petzold (eds.): The European System for the Protection of Human Rights. Dordrecht - Boston - London, 1993, Martinus Nijhoff Publishers, p. 51.

8 Korbely v. Hungary [GC] 9174/02 (19/09/2008), selected for publication in Reports of Judgments and Decisions.
} 
and Kononov v. Latvia cited earlier. ${ }^{9}$ I note at this point that I will deal more extensively with the Hungarian case.

In Kononov the ECtHR pronounced judgment on the trial of the applicant who, as established by the Latvian courts, had been involved in 1944 in the killing of Latvian villagers in retaliation for their collaboration with the Germans. The question was basically if the conviction of the applicant had any basis either in international or national law at the time of the perpetration. The ECtHR came to the conclusion that there had been no such basis and found Latvia in breach of Article 7 (1) of the ECHR. ${ }^{10}$

Korbely v. Hungary concerned events during the 1956 Hungarian Revolution. In this case the Hungarian Supreme Court upheld the conviction of the applicant who at the time of the event served as a military commander. One of the central issues in this case was whether the person killed by the applicant or upon his order qualified - due to his surrender - as a person not taking part in the hostilities and therefore came under the protection of common Article 3 of the Geneva Conventions. The ECtHR concluded that the domestic courts have not established that the victim expressed intention to surrender and therefore found Hungary in breach of Article 7 of the ECHR. The ECtHR also found that the Hungarian courts had failed to determine further criteria that make the Geneva Convention applicable and without which the applicants' conduct could not be classified as a crime against humanity.

In both Kononov and Korbely the Court was split, and both judgments have provoked already heavy criticism. ${ }^{11}$ The dissenters claimed among others that the majority went beyond its competence and while formally reiterating it, in reality, it abandoned the "no fourth instance" doctrine. Three of them accused the majority of having overruled the findings of national courts on several points stressing at the same time that the national courts were better placed than the ECtHR to

\footnotetext{
${ }^{9}$ Kononov v. Latvia 36376/04 (24/07/2008), unpublished.

${ }^{10}$ Article 7 (1) of the Convention reads as follows: "No one shall be held guilty of any criminal offence on account of any act or omission which did not constitute a criminal offence under national or international law at the time when it was committed. Nor shall a heavier penalty be imposed than the one that was applicable at the time the criminal offence was committed." The decision is not final as it has been referred to the Grand Chamber.

${ }^{11}$ See e.g. Giulia Pinzauti: The European Court of Human Rights' Incidental Application of International Criminal Law and Humanitarian Law. A Critical Discussion of Kononov v. Latvia. 6 Journal of International Criminal Justice 1043-1060 (2008 November); Cordula Droege: Elective Affinities? Human Rights and Humanitarian Law. 90 International Review of the Red Cross 871, p. 546 (2008 September).
} 
ascertain the facts and to interpret the relevant international law. ${ }^{12}$ In Korbely the dissenters blamed the majority for pretending to adhere to the principle that it is not the Court's task "to substitute itself for the domestic courts and that is primarily for the national authorities (...) to resolve problems of interpretation of domestic legislation." In fact they claimed that the majority, without any explanation, headed off in a different direction and, on a flimsy, uncertain basis, quite simply substituted its own findings of fact for those of the Hungarian judicial authorities. "In view of the complexity of the task of reconstructing the facts of the case more than fifty years after they occurred" the dissenters continued, "we see no reason to place more reliance on the conclusions reached by the Court than on those of the domestic courts. On the contrary, we consider that the national courts were in a better position to assess all the available facts and evidence."13 In the following I will try to give an answer to the question if the Court went beyond its competence and in fact abandoned the doctrine derived from the subsidiarity principle. If the answer is in the affirmative - and let me note in advance, it will be - I will seek to identify the reason for the change in the jurisprudence and how this should be assessed.

The minority, I believe is right when asserting that the Court in fact deviated from its earlier approach and, in contrast to what it claimed in both judgments, it did in fact overrule the decisions of national courts both as regards the ascertaining of the facts and the interpretation of the law. Before submitting evidence in support of my argument, I reiterate that the ECtHR judgments in Kononov and Korbely concerned historical trials, which, in addition to establishing the liability under criminal law of individual defendants, are expected to serve further ends, recording and writing history among others. Whether it is fortunate to expect any criminal trial to serve ends other than establishing individual criminal responsibility is an open question. In Thane Rosenbaum's view what makes Nuremberg "one of the great and heroic and romantic moments of the twentieth century" is that it went beyond the self-limiting and self-sabotaging goals of vindication, retribution and revenge pursued by the alienated justice system. ${ }^{14}$ Instead, Nuremberg rendered "moral justice" by providing "victims with an opportunity to have their stories told and the truth openly and publicly proclaimed and memorialized." 15 The evidence presented in Nuremberg served not only the immediate purpose of criminal trials, i.e. proving the defendant's guilt "but they also served as exhibits of

\footnotetext{
12 Joint dissenting opinion of Judges Fura-Sandström, David Thór Björgvinsson and Ziemele, par. 8, 11 and 14 .

13 Joint dissenting opinion of Judges Lorenzen, Tulkens, Zagrebelsky, Fura-Sandström and Popović, par. 2.

14 Thane Rosenbaum: Essay: The Romance of Nuremberg and the Tease of Moral Justice. 27 Cardozo Law Review 1731, 1732 (2006 February).

15 Ibid., p. 1731.
} 
history. Judgment matters, and memory matters, too."16 Bassiouni, too, sees no problem in that courts trying international crimes pursue a variety of goals: "there is nothing inherently incompatible between politically oriented goals and the achievement of the higher value of justice for the purposes of advancing the common good and, in particular cases, advancing goals pertaining to other positive outcomes, such as peace and reconciliation. As in all matters involving different and sometimes difficult goals, the balance between justice and positive political goals is hard to achieve (...). To reconcile the two is impossible, but to conciliate between them is possible." 17

Others are less enthusiastic about the multiplicity of functions historical trials are expected to fulfill. Damaska warns of the tensions created by the many demands courts trying international crimes impose on themselves. ${ }^{18}$ Also Hannah Arend's ambivalent position expressed in her book on the Eichmann trial clearly shows the difficulty of the problem. On the one hand, she seems to insist that criminal trials should be constrained to establishing individual criminal responsibility. That is why in the chapter in Eichmann in Jerusalem describing how evidence was presented and witnesses heard she expresses some discomfort over the fact that during the trial events Eichmann had nothing to do with have been discussed at length. 19 "The purpose of a trial" she writes "is to render justice, and nothing else; even the noblest of ulterior purposes, the making of a record of the Hitler regime which would withstand the test of history (...) can only detract from the law's main business: to weigh the charges brought against the accused, to render judgment, and to mete out due punishment."20 However, even this woman of fascinating intelligence fails to give robust arguments against the claim of the victims to have their day in court suggesting that she herself finds it just that survivors are given the opportunity to present their narrative of the Holocaust irrespective of Eichmann's involvement in the particular events.

Whatever our assessment as to the desirability of history-recording and historywriting through criminal trials might be, the fact remains that in proceedings for state-sponsored, state-induced or state-tolerated crimes, which by today have been formulated as international crimes, courts simply may not avoid making inquiries into events that go beyond the conduct of the individual defendant. The crimes in question are bound within the broader social and political context and it

\footnotetext{
16 Ibid., p. 1734.

17 M. Cherif Bassiouni; Perspectives on International Criminal Justice. 50 Virginia Journal of International Law 269, 293 (2010 Winter).

18 Mirjan Damaska: What is the Point of International Criminal Justice? 83 Chicago-Kent Law Review 329, 331 (2008).

19 Hannah Arendt: Eichmann in Jerusalem. A Report on the Banality of Evil. New York, 1994, Penguin Books, pp. 220-233.

20 lbid., p. 253.
} 
is exactly the context that distinguishes the crimes against mankind from ordinary criminal offenses.

Thus we simply have to accept that historical trials, in addition to ruling on individual guilt, are intended "to produce a reliable historical record of the context of international crime" and to "provide a venue for giving voice to international crime's many victims". ${ }^{21}$ And if this is the case then, one could argue, the ECtHR should be even more cautious in observing the subsidiarity principle and what follows thereof since it seems to be beyond doubt that domestic instances are much better positioned for collective history-making. For the above reasons the ECtHR should exercise maximum self-constraint both as to the re-assessment of the facts as ascertained and the interpretation of the laws as applied by national courts.

However, if we take a closer look at the rationale that justifies the "no fourth instance" doctrine, the claim we made above becomes somewhat uncertain. The rationale behind the principle that the ECtHR should accept the facts as determined in the national arena is that it is the national courts that are closest both in terms of time and space to the events they have to rule on and that it is they that may make use or benefit from the epistemological advantages of the socalled immediacy principle or principle of directness (Unmittelbarkeitsprinzip).

This, by the way, is also a principle accepted in the majority of national appeals systems: the "higher" judicial fora are generally obliged to respect the facts of the case as determined by the "lower courts", which enjoy the advantage of the immediacy principle. This is also what the principle of free proof requires: the facts of the case are arrived at by weighing the evidence, and the lower court's freedom to evaluate the evidence is virtually worthless if its assessment can be put aside by the appeals court.

However, when courts are to determine what had happened 60 or 50 years ago, when witness testimonies become relatively unreliable sources and it is primarily documentary evidence that is used in the course of the trial, then it is far less obvious that national courts are in a superior position for assessing the facts of the case. One could reasonably doubt that national courts are any better positioned to figure out what is contained in the documents than international fora.

As concerns the interpretation of laws, it is obvious that national courts are better equipped to do the job correctly. This is why the ECtHR takes an extremely cautious position in interpreting national laws even in cases when it is in fact authorized to do so. This is the case with so-called qualified rights. As a precondition for limiting numerous rights in a manner that is compatible with the Convention, the document

\footnotetext{
${ }^{21}$ Mirjan Damaska: What is the Point of International Criminal Justice? 83 Chicago-Kent Law Review 329, 331 (2008).
} 
itself establishes the rule that such limitations must be undertaken on grounds provided by national law. By referring to domestic law, the Convention makes the observance of these laws "an integral part of the engagements undertaken by the state concerned". ${ }^{22}$ If the national authorities disregard the thusly "incorporated" law, then in addition to infringing on domestic law they at the same time violate the Convention. ${ }^{23}$ However, even in these cases, the ECtHR exercises considerable self-restraint since as noted in the Winterwerp judgment: "even in those fields where the Convention 'incorporates' the rules of that law: the national authorities are, in the nature of things, particularly qualified to settle the issues arising in this connection."24

However, again the "superiority" of national courts is much less self-evident when, in addition to national law, international law is also to be applied and interpreted. Again, why should national courts be better positioned when it comes to determine the relevant international law as it stood at the time of the perpetration of the crime?

From all I have outlined above we may conclude that in reviewing historical trials the ECtHR may be justified in abandoning the "no fourth instance" doctrine. However, the majority in Kononov and Korbely claimed to have followed the traditional approach. The question is why did they think they had to adhere to the principles they follow in "ordinary cases"?

Perhaps the arguments I gave in support of setting aside the "no fourth instance" doctrine are not strong enough. I argued that in historical trials it is primarily documentary evidence that is available. But as we saw in Korbely or in Kononov witnesses had also been heard even if we may entertain certain doubts as concerns their capacity to recall the events with absolute accuracy. But still, the cognitive advantages of the immediacy principle have not been abandoned completely. And my argument regarding the interpretation of international law may also appear somewhat weak. One could put forward against my claim that ascertaining the facts may not be completely separated from their legal characterization and the interpretation of laws; therefore, if national courts are better positioned to ascertain the facts then the same applies to the interpretation of laws, be they national or international. And finally one could argue that authoritative judgment about the past is the privilege of national fora, and international bodies should abstain from interfering with the nation's collective history-making through domestic trials.

Without elaborating further on the particularities of historical trials and on the question of whether the "no fourth instance" doctrine should be observed by the

22 Herbert Petzold: The Convention and the Principle of Subsidiarity. In: R. St. J. Macdonald - F. Matscher - H. Petzold (eds.): The European System for the Protection of Human Rights. Dordrecht - Boston - London, 1993, Martinus Nijhoff Publishers, p. 50.

${ }^{23}$ See Winterwerp v. the Netherlands 6301/73 (24/10/1979), A33, par. 46.

24 Ibid. 
ECtHR when reviewing domestic historical trials, I simply claim that in both Kononov and Korbely the ECtHR failed to follow its traditional approach, without however overtly admitting it. The Court as I showed earlier made a reassessment of the facts and deviated from the interpretation municipal courts gave to the provisions of international law.

In Korbely the ECtHR reprimanded the Hungarian courts for not realizing that for common Article 3 of the Geneva Conventions to be applicable, in addition to whether at the given time there has been an armed conflict of an international character, they should have examined whether "the particular act committed by the applicant was to be regarded as forming part of [the] State policy, such as to bring it within the sphere of crimes against humanity, as this notion was to be understood in 1956." 25 The domestic courts in the view of the ECtHR also failed to consider that "it is widely accepted in international legal opinion that in order to produce legal effects such as the protection of common Article 3, any intention to surrender in circumstances such as those in issue in the present case needs to be signalled in a clear and unequivocal manner."26

III.

Still we have not answered the question of why the ECtHR departed from its traditional approach without openly admitting it. Identifying the tension between the functions historical trials are expected to perform primarily if the event the facts of which are to be ascertained occurred five or six decades earlier may bring us closer to the answer. We do accept that historical trials, in addition to ruling on individual guilt, are meant to provide a forum for collective history-making. However, the "professed goals" of historical trials "do not constitute a harmonious whole; rather they pull in different directions, diminishing each other's power and creating tensions." 27 There is a real danger that the function of producing history in trials is accomplished at the expense of reliable fact-finding in and fair assessment of the cases in question.

The difficulty in bringing these two functions in harmony was overtly admitted in Kononov by the Latvian government which, as we can read in the ECtHR's judgment, "stressed the importance of such trials in restoring democracy, establishing the historical truth and guaranteeing justice for the victims of crimes against humanity and war crimes" and argued that "despite all the practical problems with which the Latvian authorities were faced, these trials were very important as they helped to make up for the inadequacies of the Nuremberg trial, a trial that had to a large extent been an example of justice for the victors,

\footnotetext{
25 Korbely v. Hungary [GC] 9174/02 (19/09/2008), par. 84.

${ }^{26}$ Ibid., par. 90.

${ }^{27}$ Mirjan Damaska: What is the Point of International Criminal Justice? 83 Chicago-Kent Law Review 329, 331 (2008).
} 
punishing crimes perpetrated by the Nazis, while allowing notorious criminal acts by the Allies to go unpunished." 28

Thus the Government also admitted the practical problems courts in historical trials are faced with. The first problem of course is to find a case which is a good candidate for presenting a new narrative. The time factor in this context is crucial. For a trial we need a defendant, a defendant who is still alive. There are not many of them, and if the pool is limited, the chance of finding the ideal wrongdoer and the ideal victim for rewriting history is rather slim. Kononov and his victims were perhaps not the ideal players for construing a new historical narrative, and this applies to those involved in the Korbely case, too.

But the main problem is that if courts stick to the idea that they have to contribute to the emergence of the new narrative, they may be tempted to loosen the requirements of fairness when it comes to ascertaining the facts and interpreting the law. In brief, there is a risk of political justice: history is construed at the expense of the primary function of criminal trials, namely, the establishment of individual responsibility in fair proceedings.

For external observers, the ECtHR among them, it must have been certainly disquieting to see that the courts including the highest court of Hungary trying the case of Korbely at different times came to completely opposite conclusions as to the applicability of the Geneva law to the events in 1956.29 Similar discomfort must have been provoked by the fact that in 1993 the Constitutional Court, though pointing to the technical imperfections of the law adopted by Parliament that served as the basis for the conviction of the applicant, refrained from abrogating that law as unconstitutional, 30 but subsequently changed its position in 1996: it held that due to the incorrect references to various provisions of the 1949 Geneva Conventions the law was unconstitutional. ${ }^{31}$

The zealous effort of the Hungarian courts to convict the applicant produced sometimes a slip of the tongue or rather the pen revealing their bias. As indicated earlier, one of the key issues in Korbely was whether the victim whom the applicant killed had surrendered or whether he intended to use his gun. In its verdict of guilt, the Military Bench of the Regional Court held: "On the basis of the testimonies, it has not been possible to determine beyond reasonable doubt that Tamás Kaszás [the victim] was already holding the pistol in his hand in the course of the argument." 32 From this it follows that the opposite, i.e. that the victim was

\footnotetext{
${ }^{28}$ Kononov v. Latvia 36376/04 (24/07/2008), par. 92.

${ }^{29}$ Also in Kononov the Latvian courts trying the case came to different conclusions. See par. 37-46 of the judgment.

30 Constitutional Court Decision no. 53/1993 (X. 13.).

${ }^{31}$ Constitutional Court Decision no. 36/1996 (IX. 4.).

32 See Korbely v. Hungary [GC] 9174/02 (19/09/2008), par. 42.
} 
holding the pistol in his hand, may not be ruled out either. And it is a fundamental principle of fair criminal justice that it is the defendant who benefits from doubt. The judgment of the Regional Court also stated that "the defendant - presumably misunderstanding the motion of Tamás Kaszás or because of fear or shock gave a resolute order to fire."33 However, if the court assumed that the applicant was mistaken or acted in a state of mental disorganization then it should have applied the relevant sections of the Penal Code on mistake in facts or diminished mental capacity resulting in an acquittal or the mitigation of the sentence which it failed to do. The Supreme Court was watchful enough to discover what would have followed from the quoted finding of the Regional Court and omitted it by stating that from the facts ascertained by the Regional Court the correct conclusion was "that [the applicant] knew that the victim intended to hand over the gun, rather than attack with it."34

IV.

I do not list the disquieting irregularities of the trial in Korbely's case. Without further elaborating on the issue I claim: Korbely and Kononov should have been dealt with under Article 6 rather than under Article 7. In his concurring opinion in Kononov Judge Myjer also admits that he was "tempted at first to consider if - in the very specific circumstances of the case - the prosecution of the applicant was, per se, so unfair as to make the whole trial unfair." The dissenters in Korbely were also of the view that the case was wrongly brought under Article 7 of the Convention: "(A)dmittedly, the domestic courts' decisions may have left certain questions unanswered regarding the victim's conduct and the applicant's interpretation of it. However, the possible insufficiency of the reasoning of the Supreme Court's judgment could have raised an issue under Article 6 of the Convention but not, in the circumstances of the case, under Article 7." 35 In fact in Korbely the applicant, in addition to claiming a violation of Article 7, complained also of the unfairness of the proceedings. ${ }^{36}$ The ECtHR considered this complaint also admissible, however, in light of finding a violation of Article 7, it found that it was unnecessary to examine the complaint under Article 6.

The question now is why the ECtHR gave preference to examining the case under Article 7 and refrained from entertaining the complaint under Article 6. One plausible explanation is that the applicant did not specify the violation of any

\footnotetext{
33 Ibid., par. 42.

34 Ibid., par. 44.

$35 \mathrm{lbid}$., Joint dissenting opinion of Judges Lorenzen, Tulkens, Zagrebelsky, FuraSandström and Popović, par. 2.

${ }^{36}$ Also Kononov's complaint alleged violation of Article 6 (1). However this part of the application was declared inadmissible. See the admissibility decision of 20 September 2007.
} 
component of the right to fair trial as set forth in Article 6; instead he submitted, in rather general terms, that the proceedings had not been fair. ${ }^{37}$ Therefore the ECtHR would have been forced to assess the fairness of the overall proceedings. Had the ECtHR found in this particular case a violation of Article 6 due to the unfairness of the overall proceedings, this - considering the delicate nature of the trial - could also have been interpreted as a serious criticism of the entire judicial system and an expression of concerns as to the integrity of the national administration of justice.

Examining the complaint under Article 7 seemed therefore to be safer. The principle of legality embodied in Article 7 prohibits conviction in the absence of a rule at the time of the commission (prohibition of retrospective legislation). In addition, the legality principle also requires that the rule be accessible and formulated with sufficient precision. All these components are meant to guarantee that individuals can foresee for what type of acts they may be held criminally liable. Under "ordinary" conditions, by finding a violation of Article 7 the ECtHR simply proclaims that at the time of the perpetration there was no law under which the individual's conduct could be subsumed, i.e. a law was applied retroactively or that the law in question was not accessible or formulated with sufficient precision. The judgment, except when the ECtHR concludes that the law was given an extensive interpretation by analogy, makes an assessment of the law but not of the manner it was applied by national courts. That is why the "no fourth instance" doctrine can easily be observed at least as concerns the establishment of facts: the ECtHR can accept the facts as ascertained by the national fora.

However, it turned out that in Korbely the standard methodology of review works only if Article 7 is given an extremely narrow interpretation providing almost no protection. The "no fourth instance" doctrine could have been observed only if the question had been put in a very simple formulation: at the time of the fatal event (October 26, 1956) was a rule in force that was accessible to the applicant and informed him that killing of an insurgent who had laid down his arms was illegal and may have entailed consequences under criminal law? It seems to me that the question once formulated in such a simple manner would have been answered in the affirmative by the ECtHR. The Hungarian Penal Code effective at the time of the event prohibited the killing of an individual who ceased to be an attacker. Further, the ECtHR shared the Government's position that since a brochure containing the text of the Convention was officially published in 1955 the relevant Geneva law was sufficiently accessible to the applicant. ${ }^{38}$ There remains of

${ }^{37}$ The judgment also states that the applicant complained in general terms that Article 6(1) was breached. The ECtHR also held that this part of the application was admissible but in the light of finding a breach of Article 7 it decided not to examine the complaint under 6(1). See Korbely judgment, par. 96-98.

38 Ibid., par. 75. 
course the additional question of the statute of limitation: is the prosecution of the individual who at the time of the commission was properly instructed on the unlawfulness of his/her action acceptable after the expiration of the prescription period? The answer depends on how the fair warning principle is interpreted. Clearly, the principle formulates each individual's right to know "what the 'law' is at the time that they supposedly violate it." ${ }^{9}$ But the question is: "how much of the 'law' is included in this principle?" 40 The ECtHR could have adopted the view held by George P. Fletcher, who claims that according to the proper reading of the principle "individuals have a right to know that which could make a moral difference in their choosing to engage in the action or not." ${ }^{11}$ And since the statute of limitation is certainly not meant to provide guidance as to the individual's moral choice it is not covered by the nullum crimen principle.

In sum, had the ECtHR limited its review to the question whether there was a rule in October 1956 warning the applicant that the killing of a person who was no longer an attacker may entail sanction under penal law it could have easily exercised self-constraint as required by the subsidiarity principle. It could have relied on the facts as established by the Hungarian courts and had not been forced to review the manner they applied the relevant laws.

However it is exactly the statute of limitation mentioned above that may bring us closer to identifying the reason why the "no fourth instance" doctrine could not be followed in Korbely. Let us recall that the applicant was convicted for murder constituting a crime against humanity. ${ }^{42}$ Crimes against humanity make up one category of international crimes. Through the formulation of international crimes it is intended to protect values "considered important by the whole international community". ${ }^{43}$ This is the explanation for the particular jurisdictional rules, the establishment of ad hoc tribunals by the Security Council and the setting up of the International Criminal Court, as well as for that at least with regards to genocide,

39 George P. Fletcher: Basic Concepts of Criminal Law. New York - Oxford, 1999, Oxford University press, p. 12.

40 Ibid.

41 Ibid., p. 14.

42 In fact Korbely was convicted for a crime against mankind (emberiség elleni büntett/Verbrechen gegen die Menschheit) as formulated in the Hungarian Penal Code. Crimes against mankind cover two separate groups: crimes against the peace (such as incitement to war, genocide or apartheid) and war crimes. The term crimes against humanity is unknown.

43 Antonio Cassese: International Criminal Law. Oxford - New York, 2003, Oxford University Press, p. 23. 
crimes against humanity and torture international custom renders the statutes of limitation inapplicable. ${ }^{44}$

Due to the particular nature of international crimes and due to the specific values these crimes are intended to protect, the ECtHR was simply not in a position to constrain the review to the question of whether there had been a rule of whatever type warning the applicant that what he does was punishable.

There is agreement that unlike war crimes "crimes against humanity require a context of widespread or systematic commission". 45 True, the Nuremberg Charter or the 1968 New York Convention on the Non-Applicability of Statutory Limitations to War Crimes and Crimes against Humanity did not explicitly make mention of the "widespread or systematic" threshold. However we may reasonably assume that the drafters thought: this feature is a "necessary ingredient of the objective element of the crimes" 46 and therefore simply did not find it necessary to specifically refer to the systematic nature of these crimes. Thus the "widespread or systematic attack" formulation emerging in the case-law of international tribunals in the 1990s is to be interpreted as an authentic recording and clarification of one of the definitional elements of crimes against humanity. From this it follows that in the absence of "a widespread or systematic attack" the author may not be held liable for a crime against humanity: the killing, if an isolated act, may eventually constitute a war crime but not a crime against humanity. ${ }^{47}$ But even if it can be established that at the time of the perpetration of the individual offense inhumane acts were committed on a wide scale or systematically for holding an individual liable for a crime against humanity, it must be proven that the agent was "cognisant of the link between his misconduct and a policy or systematic practice." 48

In the ECtHR's view the Hungarian courts confined their inquiry to determining the level of intensity of conflicts that make the Geneva Conventions applicable without however examining the existence of further "international law elements

\footnotetext{
44 Ibid., p. 319. The UN Convention of 1968 and the 1974 European Convention extend the non-applicability of the statutes of limitation also to war crimes but these treaties have been ratified by only a relatively few states. See Ibid., p. 317.

${ }^{45}$ Robert Cryer - Håkan Friman - Darryl Robinson - Elizabeth Wilmshurst: An Introduction to International Criminal Law and Procedure. Cambridge, 2007, Cambridge University Press, p. 190.

46 Antonio Cassese: International Criminal Law. Oxford - New York, 2003, Oxford University Press, p. 65.

${ }^{47}$ Robert Cryer - Håkan Friman - Darryl Robinson - Elizabeth Wilmshurst: An Introduction to International Criminal Law and Procedure. Cambridge, 2007, Cambridge University Press, p. 190.

48 Antonio Cassese: International Criminal Law. Oxford - New York, 2003, Oxford University Press, pp. 81-82.
} 
inherent in the notion of crimes against humanity", among them "the requirement that the crime should not be an isolated or sporadic act but should form part of 'State action or policy' or of a widespread and systematic attack on the civilian population." 49 In other words the ECtHR's position is that the Hungarian courts erroneously believed that for establishing criminal liability for a crime against humanity under common Article 3 it is sufficient if it is proven that the intensity of hostilities in October 1956 reached the level of an armed conflict.

The "no fourth instance" doctrine says that it is not the task of the ECtHR to substitute itself for the domestic jurisdictions, i.e. it is for national courts to ascertain the facts as well as to resolve problems arising in the course of interpreting legislation. The Court's role is confined to assessing if the way national courts established the facts and interpreted the law was compatible with the Convention. The Court's task is to listen to the music played by the national orchestra reading the score and decide if the performance was above the acceptable level. What it should not do is to play the piece itself and then compare its own performance with that of the national orchestra. However, in order for the Court to ascertain whether the national court's performance was satisfactory they both have to read the same music. If the national orchestra plays a Vivaldi concerto whereas it is expected to play a Beethoven symphony then the ECtHR has no other choice than to grade the performance sub-standard. And in order to convince the audience of the correctness of its decision it must play the piece the national orchestra was expected to perform. It seems that this was what happened in Korbely. The domestic courts promised that they would ascertain that the applicant had committed a crime against humanity but failed to extend their inquiry to those elements that make up a crime against humanity. And the ECtHR explained what the national courts should have done.

One could argue that the ECtHR should have left to the national courts the determination of what conduct qualifies as a crime against humanity. In fact the ECtHR states that even if domestic law makes reference to international law it is for national courts to resolve problems of interpretation. ${ }^{50}$ However, as I claimed earlier, the "superiority" of national courts to interpret legislation is much less selfevident when in addition to national law international law is also to be applied and interpreted. It is by no means obvious why national courts should be better positioned to determine the content of the relevant international law as it stood at the time of the perpetration of the crime.

The judgment of the ECtHR implicitly declares that the national courts have not been aware of what transforms an "ordinary crime" into a crime against humanity. Though the judgment found Hungary in breach of Article 7, what the Court declared

\footnotetext{
${ }^{49}$ Korbely v. Hungary [GC] 9174/02 (19/09/2008), par. 82-83.

50 lbid., par. 72.
} 
was that the facts as established by the Hungarian Supreme Court did not qualify as a crime against humanity. Therefore it is unfortunate to speak about a violation of Article 7 since this suggests that law adopted subsequent to the commission was applied retroactively. But as is clear from the sources invoked by the ECtHR, the "contextual threshold" has not been abandoned in our day and, similarly, the rule that in order to qualify as a person hors de combat that person must clearly express an intention to surrender is still valid. Thus we hardly could state that any law was applied retroactively. Surely, Article 7 is also violated if the defendant is convicted for conduct that neither at the time of the "perpetration" nor at the time of the verdict constituted a criminal offense. But this again was not the case in Korbely: in October 1956 the category of crimes against humanity did, of course, exist but the conduct with which the applicant was charged did not fit into that category. Thus it was the erroneous legal characterization of the facts that rendered the judgment of the Hungarian Supreme Court deficient.

The ECtHR should not be blamed for substituting its own position for the legal assessment made by the Supreme Court; as I argued in the case of interpreting international law the national authorities are certainly not better positioned to make the correct assessment. In addition, respect for the legal characterization made by national fora has its limits: if the assessment is devoid of any reason, if it is clearly arbitrary, the ECtHR has to overrule it. This was also the case in Lukanov 51 where the Court had to determine if the conduct, which served as the basis of the applicant's detention, constituted a criminal offense. Contrary to what had been found by the domestic authorities the ECtHR concluded that "there was not even the slightest possibility that [the] conduct could have constituted an offence"52 and found a breach of Article 5. Whereas in Lukanov the incorrect classification of the conduct as a criminal offense was a result of "a clear abuse of power" 53 , in Korbely it was the misinterpretation of the concept of crimes against humanity that induced the ECHR to overrule the conclusion drawn by the Hungarian Supreme Court.

Some argue that through its judgment in Korbely the ECtHR nullified the efforts taken by the Hungarian State to punish crimes committed under the communist regime. ${ }^{54}$ By this it has unintentionally questioned the official narrative of the 1956 events in Hungary. I would argue that Korbely rather shows the difficulties of accomplishing multiple functions in historical trials. I am inclined to assume that in the period between October 23 and November 4, 1956 there have been atrocities

\footnotetext{
51 Lukanov v. Bulgaria 21915/93 (20/03/1997), Reports 1997-II.

52 Stefan Trechsel: Human Rights in Criminal Proceedings. Oxford, 2006, Oxford University Press, p. 426.

53 Ibid.

54 Márton Varjú: Transition as a Concept of European Human Rights Law. p. 15. Available at: http://papers.ssrn.com/sol3/papers.cfm?abstract_id=1329978\&download=yes (last visited: 22 July 2009).
} 
that could qualify as crimes against humanity. There have been cases where the link between a central policy to commit crimes against humanity and the conduct of identifiable individuals could have been established. ${ }^{55}$ The ECHR ruled that Korbely did not come under this category. The judgment of the Court demonstrates once more the difficulties to find the proper candidate for presenting a new account of history through trials conducted five decades after the events have taken place.

\section{SUMMARY}

Tribunals trying international core crimes are expected to accomplish a number of objectives in addition to standard aims of criminal justice. Decisions rendered in so-called historical trials, among others, give an assessment of the past, set down a permanent and authoritative record of history, and the impact of such decisions goes well beyond the individual case. The paper explores two judgments of the European Court of Human Rights (ECtHR) rendered in the year 2008. Both in Kononov v. Latvia and in Korbely v. Hungary the ECtHR found a violation of article 7 of the European Human Rights Convention (ECHR), which requires that no one should be convicted except for breach of an existing rule of law. In both cases the ECtHR was split, and the judgments provoked heavy criticism.

The author argues that in both cases the ECtHR abandoned its earlier position to leave the ascertaining of the facts and their legal classification to the domestic agencies and confine itself to reviewing if the law was applied in line with the ECHR. The author claims that the ECtHR was wrong in bringing the cases under Article 7 of the ECHR. Instead it should have examined the applications under Article 6 , and if concerned about the irregularities of the trials and the arbitrary application of the relevant legal provisions, it should have found a breach of the defendant's right to a fair trial. The reason for the ECtHR's option in the author's view is that the Court in its effort not to question the legitimacy of using the criminal process for coming to terms with the past did not wish to proclaim that the entire domestic trial had been unfair. Thus it appeared safer to bring the cases under Article 7. However the Court had to pay dearly for its political discreteness.

\section{SOMMAIRE}

Les Tribunaux qui jugent les crimes internationaux sont tenus d'accomplir un certain nombre d'objectifs en plus des objectifs classiques de la justice pénale. Parmi d'autres, les décisions rendues dans ce qu'on appelle les procès historiques, donnent une évaluation du passé, fixent un récit de l'Histoire permanent et faisant autorité, et l'impact de ces décisions dépasse le cadre du cas individuel. L'article étudie deux arrêts de la Cour européenne des Droits de l'homme (CEDH) qui ont été rendus en 2008. Dans l'arrêt Kononov c. Lettonie comme dans celui de Korbely c. Hongrie, la CEDH a conclu à une

55 See Tamás Hoffmann: Individual Criminal Responsibility for Crimes Committed in Noninternational Armed Conflicts - The Hungarian Jurisprudence on the Volley Cases. In: Stefano Manacorda - Adán Nieto (eds.): Criminal Law Between War and Peace: Justice and Cooperation in Criminal Matters in International Military Interventions. Cuenca, 2009, Ediciones de la Universidad de Castilla-La Mancha, pp. 735-753. 
violation de l'article 7 de la Convention européenne des Droits de l'homme (CEDH), qui exige que nul ne doit être condamné sans la violation, de sa part, d'une infraction préalablement reconnue par la Loi. Dans les deux cas, la CEDH a été divisée, et les jugements rendus ont provoqué de fortes critiques.

L'auteur soutient que, dans les deux cas, la CEDH a abandonné sa position antérieure qui était celle de laisser la constatation des faits et leur qualification juridique aux autorités judiciaires nationales et de se borner à examiner si la loi avait été appliquée en conformité avec la CEDH. L'auteur affirme que le CEDH a eu tort d'utiliser l'article 7 de la CEDH pour ces affaires. Au contraire, elle aurait dû examiner les demandes au titre de l'article 6 et, si elle était préoccupée par les irrégularités du procès et par l'application arbitraire des dispositions légales, elle aurait dû aboutir à violation du droit de l'accusé à un procès équitable. Pour l'auteur, la raison du choix fait par la CEDH est que la Cour ne veut pas proclamer que l'ensemble du procès national a été inéquitable, et ce, pour ne pas remettre en cause la légitimité de l'utilisation faite de la procédure pénale ayant permis de venir à bout du passé. Ainsi, il semble plus sûr de porter ces affaires devant la CEDH au titre de la violation de l'article 7 . Toutefois, la Cour a dû payer cher sa politique discrétionnaire.

\section{RESUMEN}

Se espera que los tribunales que juzgan los crímenes internacionales más graves (core crimes) alcancen una serie de objetivos, además de los objetivos habituales de la justicia penal. Las decisiones adoptadas en los llamados juicios históricos, entre otros, hacen una valoración del pasado, estableciendo un registro permanente y oficial de la historia, y el impacto de tales decisiones va más allá del caso individual. El trabajo examina dos sentencias del Tribunal Europeo de Derechos Humanos (TEDH) del año 2008. Tanto en Kononov c. Letonia como en Korbely c. Hungría el TEDH consideró que existía una violación del artículo 7 del Convenio Europeo de Derechos Humanos (CEDH), de acuerdo con el cual nadie puede ser condenado por una acción o una omisión que, en el momento en que haya sido cometida, no constituya una infracción según el Derecho vigente. En ambos casos, el Tribunal de Derechos Humanos estuvo dividido, y las sentencias fueron objeto de fuertes críticas.

El autor sostiene que en ambos casos el TEDH abandonó su posición anterior consistente en dejar el establecimiento de los hechos y su calificación jurídica a los organismos nacionales y limitarse a examinar si la ley se ha aplicado de acuerdo con el CEDH. El autor afirma que el TEDH se ha equivocado al examinar el caso de acuerdo con el artículo 7 del CEDH. Por contra, se deberían haber examinado las demandas de acuerdo con el artículo $6 \mathrm{y}$, de estar preocupado por las irregularidades de los juicios y la aplicación arbitraria de las disposiciones legales pertinentes, debería haberse declarado la existencia de una violación del derecho del acusado a un juicio justo. La razón de la opción del TEDH, en opinión del autor, es que, en su esfuerzo por no cuestionar la legitimidad de la utilización del proceso penal para hacer las paces con el pasado, el Tribunal no ha querido declarar que el proceso nacional en su totalidad había sido injusto. Por lo tanto, parecía más seguro enjuiciar los casos de acuerdo con el artículo 7. Sin embargo, el Tribunal tuvo que pagar cara su discrecionalidad política. 